ELORE (ISSN 1456-3010), vol. $16-2 / 2009$.

Julkaisija: Suomen Kansantietouden Tutkijain Seura ry.

[http://www.elore.fi/arkisto/2_09/ajankoht_hammarstrom_2_09.pdf]



\title{
Ajankohtaista
}

\section{NÄKÖKULMIA KULTTUURIPERINTÖÖN}

\author{
Kulttuuriperintö. Suomen Kansantietouden Tutkijain Seuran IV kevätkoulu 15.5.2009 Hel- \\ singissä
}

\section{Kukka Hammarström}

Suomen Kansantietouden Tutkijain Seura ry järjesti jälleen toukokuun puolivälissä päivän mittaisen kevätkoulun Helsingissä Tieteiden talolla. Tällä kertaa aiheena oli kulttuuriperintö, joka liittyi näin myös Eloren uusimpaan, samaa aihepiiiriä käsittelevään teemanumeroon. Päivän kuluessa kävi selväksi, että kulttuuriperintöä voidaan lähestyä hyvin moninaisista näkökulmista. Keskeisesti esiin noussut seikka oli kulttuuriperinnön dynaamisuus ja sen määrittelyn sekä arvottamisen varioiminen paikallisesti ja ajallisesti. Esimerkiksi paikallisten pienryhmien ja UNESCOn kaltaisen kansainvälisen toimijan käsitykset kulttuuriperinnön sisällöistä ja arvosta saattavat poiketa toisistaan. Erilaiset neuvottelut ja ristiriitatilanteet ovatkin osa kulttuuriperintöä koskevaa keskustelua ja toimintaa. Toisaalta tulee muistaa, että myös kulttuuriperintöön kohdistuva tutkimus ottaa osaa tähän keskusteluun.

\section{MERKITYKSIÄ, ARVOKYSYMYKSIÄ JA RISTIRIITOJA}

Tuulikki Kurki (Joensuun yliopisto) avasi seminaarin ja kertoi seuran toimintaan liittyvistä ajankohtaisista asioista. Seuralle on valittu uusi johtokunta ajalle 2009-2011, ja Eloren ilmestymiselle kaksi kertaa vuodessa on edelleen hyvät edellytykset. Tavoitteena on myös seuran toiminnan kehittäminen ja jäsenistön tavoittaminen. Samalla julkistettiin seuran toteuttama valokuvauskilpailu aiheesta "tutkimus". Kurki pohti puheenvuorossaan myös sitä, miten kulttuuriperintöä määritellään ja arvotetaan esimerkiksi erilaisten toimijoiden, kuten instituutioiden, julkisten ja yksityisten ryhmien tai yksilöiden näkökulmasta. Ajankohtaisina asioina kulttuuriperintöä koskevassa 


\section{NÄKÖKULMIA KULTTUURIPERINTÖÖN}

keskustelussa hän toi esiin muun muassa erilaiset digitaaliset hankkeet, kuten yhteisen eurooppalaisen "digitaalinen kirjasto" -hankeen, kulttuurimatkailun sekä kysymykset vallankäytöstä ja kulttuuriperintö-prosessin tuottamisesta.

Petja Aarnipuu (Helsingin yliopisto) lähestyi aluksi kulttuuriperintöä kehä-kuvauksen kautta. Kehät muodostuvat erilaisista tasoista, kuten yksilöistä, paikallisyhteisöstä, kansakunnasta ja ihmiskunnasta. Liikkeen kautta ne ovat yhteydessä toisiinsa. Hän totesi, että esimerkiksi se, mikä on ainutlaatuista pienyhteisölle, saattaa olla matkailun kautta yhteydessä laajempaan, maailmanlaajuiseen kenttään. Aarnipuu nosti esiin myös 1800-luvun kansalliset projektit, jotka olivat osa ihmiskunnan sivistyshistoriaksi kutsuttua ajattelutapaa. Kansalliseen projektiin liittyivät Suomessa esimerkiksi Kansallismuseon synty ja tärkeys sekä Suomalaisen Kirjallisuuden Seuran keruut ja arkistot, joiden kautta voitiin osaltaan osoittaa kuuluminen maailman sivistyskansoihin. Aarnipuu käytti esimerkkinä myös Edinburgin kaupunkia, joka kulttuuriperintökohteena on matkailukohde mutta samalla koti: asetelma, joka aiheuttaa ristiriitoja ja törmäyksiä turistien ja paikallisten asukkaiden välille.

Kenen omaisuutta kulttuuriperintö sitten on? Entä edellyttääkö sen säilymisen paikalleen jähmettymistä ajassa ja tilassa? Kulttuuriperintö on muuttuvaa ja jatkuvassa liikkeessä. Se muotoutuu valintojen kautta ja ihmisten välisessä kommunikaatiossa. Aarnipuu myös esitti näkemyksen, jonka mukaan kulttuuriperintö on maailman hahmottamisen ja siitä viestimisen tapa. Siihen liittyvät myös toisten kulttuuriperinnön hahmottaminen ja tunnistaminen sekä oman elinympäristön ymmärtäminen osana maailmaa. Kommenttipuheenvuoroissa pohdittiin vielä kulttuuriperintöön kohdistuvan tutkimuksen kantaaottavuutta sekä kulttuuriperintöön liittyvää poliittista argumentointia.

Jyrki Pöysä (Joensuun yliopisto) pohti esityksessään nostalgian, historian ja paikallisuuden merkityksiä työn performatiivisuuden kautta. Työn perusmerkitys on tuottaa toiminnallaan jotakin. Toisaalta työ voi saada myös esityksellisiä piirteitä ja sitä voidaan esittää tuotannon ulkopuolella. Esimerkkinä tästä Pöysä nosti esiin muun muassa kotiseutuopetuksen, kylä- ja kaupunginosahankkeet ja museoiden työnäytökset sekä metsätyöperinteen. Nostalgiaa ruokkivat niin kutsutut perinteiset työtavat (kuten vaikkapa tervanpoltto tai koskenlasku) eivät välttämättä edellytä muistoja, vaan nostalgia voi rakentua kuvitelmien varaan. Toisaalta tämä nostaa pintaan kysymys siitä, miksi tietyt työtavat nousevat esittämisen kohteiksi ja toiset taas eivät. Lopuksi Pöysä mietti myös esimerkkinä olleeseen metsätyöperinteeseen liittyvien tukkilaiskisojen kulttuuriproblematiikkaa sekä kysymystä siitä, mitä vaikkapa nykyajassa tapahtuva (ja esitettävä) koskenlasku oikeastaan edustaa.

Johanna Björkholm (Åbo Akademi) keskittyi tarkastelemaan niin kutsututtua aineetonta kulttuuriperintöä. Esimerkkinä hän toi esiin suomenruotsalaisen kansanmusiikin sekä perinteen arvottamisen ja siihen liittyvät erilaiset tulkinnat. Kulttuuriperintö ei ole olemassa sellaisenaan, objektiivisesti, vaan siihen liittyy aina valintoja, tulkintoja ja merkityksellistämistä. Lähestyttäessä kulttuuriperintöä folkloren kautta voidaan Björkholmin mukaan analysoida sitä, mitä folkloren osa-alueita nostetaan esiin erityisen merkityksellisinä. Hän huomioi myös, että kulttuuriperintöön liittyy laajempi ajallinen ja historiallinen perspektiivi. Toisaalta kulttuuriperintöä voidaan tarkastella osana tieteellistä keskustelua. 


\section{KULTTUURIPERINTÖ JA MATKAILU}

Joonas Ahola (Helsingin yliopisto) vei kuulijat "satujen saarelle" Islantiin. Hän pohti kulttuuri- tai matkailutuotteen merkitystä sen tuottajalle ja toisaalta oletetulle turistille. Saagat ovat osa islantilaista identiteettiä ja näin myös matkailua. Ahola esitteli Reykjavikissa sijaitsevaa Sagamuseumia jossa saagoja on käytetty historian esittämissä niin, että niistä on valikoitu oletettavasti matkailijaa kiinnostavia elementtejä. Toinen esimerkki liittyi pieneen syrjäseudun kylään, jossa alueen viikinkimatkailu on liittänyt saagojen menneisyyden paitsi välineelliseksi osaksi matkailua myös paikallisten elämää ja toimintaa. Pienen kylän vuosittaisen kyläjuhlan osallistujista enemmistö on paikallisia, kun taas pääkaupunkiseudun museossa vierailee paljon turisteja. Toisaalta syrjäisempien alueiden matkailuprojektit ovat niiden elpymisen kannalta tärkeitä, sillä ne tuovat alueille kansallista sekä EU:n myöntämää taloudellista tukea. Ahola nostikin esiin myös Islannin alueellisen matkailusuunnittelun ja sen erilaiset vaatimukset.

Tuomas Hovi (Turun yliopisto) keskittyi esityksessään Aholan tavoin kulttuuriperintöön ja matkailuun. Hän käytti esimerkkinään Romanian Dracula-turismia. Romaniassa kulttuuriperintökohteet liittyvät fiktiiviseen, kirjailija Bram Stokerin luomaan vampyyrikreivi Draculaan, historialliseen hallitsijaan Vlad Seivästäjään ja kohteisiin, jotka eivät liity kumpaankaan edellä mainittuun henkilöön sekä UNESCOn kohteisiin. Jotkut kohteet saattavat kuitenkin liittyä myös useampiin merkitysyhteyksiin. VampyyriDraculaan liittyvää turismia on Romaniassa vastustettu siksi, että se on ulkopuolelta tuotettu ja antaa väärän kuvan maasta ja sen historiasta. Toisaalta Dracula-turismi tuo matkailijoita, joille voidaan samalla esitellä muita tärkeitä kulttuurikohteita. Hovi pohti myös, että turismin ja kulttuuriperinnön suhteessa ei ole kyse vain tuhoamisesta vaan säilyttämisestä ja säilymisen mahdollisuudesta. Kommenttipuheenvuorossaan folkloristiikan emeritaprofessori Annikki Kaivola-Bregenhøj (Turun yliopisto) nosti esiin kulttuuriperinnön määrittelyn varioinnin ja uudelleen märittelyn eri aikoina.

Lopuksi esiteltiin vielä uusinta Eloren numeroa $(1 / 2009)$ sekä pohdittiin kevätkoulun tulevaisuutta, muotoa ja tulevia aiheita. Esiin nousi myös ehdotuksia kulttuuriperintöaiheisesta julkaisusta sekä Eloren mahdollisesta painetusta vuosikirjasta.

\section{Filosofian maisteri Kukka Hammarström on jatko-opiskelija Turun yliopiston} folkloristiikan oppiaineessa. 